\title{
Pertanggungjawaban Pidana Pelaku Perbuatan Persiapan dalam Tindak Pidana Terorisme
}

\author{
Fandy Ardiansyah Catur Santosa \\ fandy_shogun@yahoo.com \\ Universitas Airlangga
}

\begin{abstract}
Terrorism began to flare up after the attack on the 2001 WTC building in the United States. Terrorism which carried out its action in Indonesia is well known after the Bali bombings in 2002. Many terrorists in Indonesia are motivated by ideological factors that want Indonesia to become an Islamic state without being influenced by other countries that are predominantly non-Muslim or controlled by citizens who are non-Muslim, therefore if it is not achieved, then the terrorists will carry out jihad in accordance with their beliefs. This study raises the problem : the qualifications for preparations in the criminal act of terrorism that have been regulated in the new law concerning Eradication of Terrorism Crimes Number 5 of 2018 concerning Amendments to Law Number 15 of 2003 concerning the Establishment of Goverments Regulations in lieu of Law number 1 of 2002 concerning Eradication of Acts Criminal Terrorism becomes the previous law whereby the old law is reactive in this case waiting for the arrival of new incidents that have the authority to act. Therefore, the new law regulates the preparation and accountability for preparatory of criminal acts of terrosism.

Keywords: Terrorism in Indonesia; Acts of Preparation in Criminal Acts of Terrorism; Accountability for Preparatory Acts in Criminal Acts of Terrorism.
\end{abstract}

\begin{abstract}
Abstrak
Terorisme mulai marak melakukan aksinya setelah penyerangan terhadap gedung WTC tahun 2001 di Amerika Serikat. terorisme yang melakukan aksinya di indonesia terkenal setelah peristiwa bom bali tahun 2002. teroris di indonesia banyak dilatarbelakangi oleh faktor ideologi yang menginginkan indonesia menjadi negara islam tanpa dipengaruhi oleh negara lain yang mayoritas beragama non muslim ataupun dikuasai oleh warga yang beragama non muslim, oleh karena itu jika tidak tercapai keinginannya, maka para teroris akan melakukan jihad sesuai dengan keyakinannya. Penelitian ini mengangkat masalah : kualifikasi perbuatan persiapan dalam tindak pidana terorisme yang diatur di undang-undang yang telah direvisi yakni Undang-Undang Pemberantasan Tindak Pidana Terorisme Nomor 5 tahun 2018 tentang Perubahan atas Undang - Undang Nomor 15 tahun 2003 tentang Penetapan Peraturan Pemerintah Pengganti Undang - Undang nomor 1 tahun 2002 tentang Pemberantasan Tindak Pidana Terorisme menjadi Undang - Undang yang dahulu undangundang yang lama bersifat reaktif yang dalam hal ini menunggu datangnya kejadian baru aparat yang berwajib bertindak. Oleh karena itu di undang-undang yang baru tersebut sudah mengatur perbuatan persiapan dan juga pertanggungjawaban bagi pelaku tindak pidana terorisme.

Kata Kunci: Terorisme di Indonesia; Perbuatan Persiapan dalam Tindak Pidana Terorisme; Pertanggungjawaban Perbuatan Persiapan.
\end{abstract}

\section{Pendahuluan}

Aksi teror banyak terjadi diberbagai belahan dunia, dimana aksi para teroris mempunyai alasan dan tujuan yang berbeda untuk melakukan aksi teror tersebut. Aksi-aksi teror tersebut telah menimbulkan banyak korban jiwa dan rusaknya 
fasilitas umum, puncak serangan teroris yang sempat mengguncang dunia tersebut menimpa Amerika Serikat yang terjadi di World Trade Center (WTC) pada tanggal 11 September 2001 yang menelan korban jiwa sebanyak 2.970 orang. Di antara peristiwa pemboman yang terjadi di Indonesia, peristiwa yang sempat menyentakkan dunia khususnya Indonesia adalah bom yang terjadi di Bali pada tanggal 12 Oktober 2002 sekira pukul 23.05 Wita yang terjadi di Sari's Club dan Paddy,s Club yang merenggut nyawa sebanyak 202 (dua ratus dua) orang, peristiwa ini dikenal dengan sebutan Bom Bali I. Korban sebanyak 202 (dua ratus dua) sebagian besar adalah warga negara asing dan sebagian warga negara Indonesia. Peristiwa Bom Bali I ini dilakukan oleh pelaku yang terlatih yang dalam hal ini bisa dilihat dengan metode yang digunakan pelaku dengan terlebih dahulu melakukan pengalihan perhatian dengan adanya dua bom yang meledak, dimana bom pertama berfungsi untuk pengalihan bom utamanya. Bom pertama diledakkan oleh Isa alias Feri dalam Paddy's Club dengan cara bom bunuh diri, yang mana bom tersebut diletakkan dalam sebuah rompi yang dipakai oleh Isa atau Feri kemudian diledakkan. Setelah bom meledak dan para pengunjung Paddy's Club berlarian keluar, tidak lama kemudian Arnasan alias Jimi meledakkan bom yang diletakkan dalam sebuah mobil L-300 yang diparkir di depan Sari's Club yang terletak tidak jauh dari Paddy's Club. ${ }^{1}$

Setelah terjadinya bom yang terakhir di Gereja Katholik Santa Maria Tak Bercela, GKI Diponegoro, GPPS Jemaat Sawahan Surabaya pada tanggal 13 Mei 2018, Pemerintah Indonesia akhirnya mengesahkan perubahan atas Undang-Undang Nomor 15 tahun 2003 tentang Penetapan Peraturan Pemerintah Pengganti UndangUndang Nomor 1 tahun 2002 tentang Pemberantasan Tindak Pidana Terorisme menjadi Undang-Undang Nomor 5 tahun 2018 pada tanggal 22 Juni 2018 yang mendefinisikan tentang perbuatan terorisme dalam Pasal 1 ayat (2) yaitu:

"Terorisme adalah perbuatan yang menggunakan kekerasan atau ancaman kekerasan yang menimbulkan suasana teror atau rasa takut secara meluas,

${ }^{1}$ Renne R. Kawilarang, 'Mengenang Tragedi Bom Bali 2002' (2008) <https://www.viva. co.id/arsip/2291-mengenang-tragedi-bom-bali-2002> accessed 20 September 2018. 
yang dapat menimbulkan korban yang bersifat massal, dan/atau menimbulkan kerusakan atau kehancuran terhadap objek vital yang strategis, lingkungan hidup, fasilitas publik, atau fasilitas internasional dengan motif ideologi, politik, atau gangguan keamanan”.

Bahwa langkah represif yang dilakukan oleh pemerintah untuk menanggulangi kasus terorisme diantaranya pembentukan Badan Nasional Penanggulangan Terorisme, serta pembentukan satuan khusus seperti Densus 88 POLRI maupun Detasemen Penanggulangan Terorisme (Gultor TNI) sebagai langkah dalam menemukan pelaku tindak pidana terorisme dan penjatuhan sanksi pidana yang tegas terhadap pelaku terorisme berdasarkan bukti yang telah ada dan konsep deradikalisasi mengacu kepada tindakan pencegahan bahaya terorisme dengan menetralisir paham yang dianggap radikal dan membahayakan bagi negara melalui pendekatan tanpa melalui kekerasan dengan cara membuat kebijakan baru dimana para narapidana kasus terorisme diberikan pemahaman tentang masalah sosial, hukum yang berlaku di Indonesia, menanamkan nilai-nilai perdamaian agar pemikiran radikal dari para narapidana terorisme mulai hilang, maka dari itu konsep deradikalisasi sangat diperlukan sebagai penanggulangan dan pencegahan pemahaman yang bersifat radikal seperti kejahatan terorisme.

Karakter pendekatan preventif dengan masuk ke dalam kehidupan bermasyarakat lewat peringatan dini (early warning) yang melibatkan peran serta aparat keamanan yang dalam hal ini POLRI dan TNI kemudian para pendidik di lingkungan Pendidikan, tokoh agama, tokoh masyarakat. Atas pedoman tersebut, rancangan deradikalisasi seyogyanya memberikan langkah-langkah pencegahan untuk mendeteksi terhadap ancaman dan sumber-sumber aksi terorisme yang dapat diantisipasi secara dini, serta mendalami dalam pengungkapan jaringan terorisme yang dapat mencegah dan mengeliminasi perekrutan pelaku aksi teror. Semua ini masih ranah peran dan fungsi penegakan hukum dan dalam rangka memelihara keamanan dan ketertiban umum. ${ }^{2}$

\footnotetext{
2 Indriyanto Seno Adji, 'Revisi UU Terorisme, Penegakan Hukum, Dan Perlindungan HAM' (Kompas, 2016) <https://nasional.kompas.com/read/2016/07/17/06414571/revisi.uu.terorisme.penegakan.hukum.dan.perlindungan.ham?page=all $>$.
} 
Revisi undang-undang terorisme tersebut mengusung konsep deradikalisasi yang memberikan langkah-langkah preventif untuk mendeteksi terhadap ancaman dan sumber-sumber aksi terorisme yang dapat mengantisipasi secara dini, serta mengupayakan dalam pengungkapan jaringan terorisme agar dapat mengantisipasi dan mengurangi perekrutan pelaku aksi teror. Semua ini masih ranah peran dan fungsi penegakan hukum dan dalam rangka memelihara keamanan dan ketertiban umum dan dapat mendeteksi mengenai perbuatan persiapan yang dikualifikasikan sebagai tindak pidana terorisme dan pertanggungjawaban pelaku dalam tindak pidana terorisme.

\section{Kualifikasi perbuatan persiapan yang dapat dipidana berdasarkan Undang-Undang tentang Pemberantasan Tindak Pidana Terorisme}

Berdasarkan rumusan pasal 53 ayat (1) KUHP, unsur-unsur percobaan adalah:

1. Niat (voornemen), yang berarti sudah mempunyai rencana untuk perbuatan yang bertentangan dengan aturan hukum;

2. Permulaan Pelaksanaan kejahatan sudah dilakukan dalam perbuatan yang bertentangan dengan aturan hukum;

3. Keadaan, yakni pelaksanaan perbuatan tersebut belum selesai karena tertahan oleh sesuatu keadaan selanjutnya, namun bukan karena kehendak dari pelaku.

Dipenuhinya unsur-unsur tersebut maka suatu perbuatan dapat dikualifikasikan sebagai tindak pidana percobaan. Terdapat beberapa bentuk-bentuk percobaan meliputi percobaan selesai, percobaan tertunda, percobaan yang dikualifisir, dan percobaan tidak mampu.

Unsur-unsur subjektif dari suatu tindak pidana ialah:

1. Kesengajaan atau ketidaksengajaan (culpa/dolus);

2. Niat atau voornemen yang dipersyaratkan dalam percobaan atau pogging yang diatur dalam Pasal 53 ayat (1) KUHP;

3. Maksud atau oogmerk seperti dalam kejahatan pencurian, penipuan, pemerasan, pemalsuan dan lain-lain;

4. Dengan merencanakan kejahatan terlebih dahulu atau voorbedakteraad seperti dalam kejahatan pembunuhan menurut pasal 340 KUHP;

5. Perasaan takut atau vrees seperti seorang ibu yang ketakutan tahu bahwa dirinya akan melahirkan dalam rumusan tindakan menurut pasal 308 KUHP. 
Unsur-unsur objektif dari suatu tindak pidana ialah:

1. Perbuatannya memiliki sifat melanggar aturan hukum;

2. Kualitas dari pelaku tindak pidana yakni orang yang dijatuhkan sanksi pidana harus mempunyai kesalahan (asas tiada pidana tanpa kesalahan);

3. Subjek atau pelaku tindak pidana dapat dipidana jika pelaku tersebut dapat mempertanggungjawabkan perbuatannya dan tidak mengalami gangguan kejiwaan karena apabila pelaku mengalami gangguan jiwa maka perbuatannya tidak dapat dipertanggungjawabkan. ${ }^{3}$

Mengkategorikan terorisme sebagai suatu tindak pidana, maka unsur objektif dan subjektif dari suatu tindak pidana wajib ada dalam tindakan terorisme. Unsur yang pertama yaitu unsur melawan hukum yang memiliki dua pengertian, yaitu yang pertama yakni melawan hukum secara formil yaitu ajaran yang diatur oleh undang-undang yang kemudian ajaran formil ini tidak memberikan rumusan tindak pidana diluar dari undang-undang pidana karena yang tercantum tersebut merupakan delik. Sedangkan yang dimaksud melawan hukum secara materil adalah tidak hanya melakukan sesuatu perbuatan yang dilarang dalam undang-undang, namun juga perbuatan yang dilarang berdasarkan asas hukum yang tidak tertulis seperti norma dan adat istiadat yang berlaku.4 Ajaran hukum materiil ini hanya ingin menyempurnakan kaidah melawan hukum formil yang yang tidak saja bersumber dari undang-undang namun hukum yang berlaku dalam bermasyarakat yang berupa hukum pidana adat maupun kebiasaan sebagai norma. Dalam penerapan unsur perbuatan melawan hukum dalam proses pembuktian tindak pidana sangat berguna pada saat proses pembuktian di persidangan. Apabila seseorang yang melakukan perbuatan yang telah memenuhi unsur melawan hukum, maka dalam proses persidangan, jaksa penuntut umum harus dapat membuktikan unsur tersebut karena unsur melawan hukum ini adalah syarat untuk dimintai pertanggungjawaban, namun jika unsur melawan hukum tersebut tidak terbukti maka putusannya vrijspraak atau putusan bebas. Sedangkan, jika unsur melawan hukum hukum tidak secara tegas merupakan unsur dari suatu tindak pidana maka tidak terbuktinnya unsur tersebut

\footnotetext{
${ }^{3}$ P.A.F Lamintang, Dasar-Dasar Hukum Pidana Indonesia (Sinar Baru 1990).[172].

${ }^{4}$ ibid.[185].
} 
menyebabkan putusannya lepas dari segala tuntutan hukum. ${ }^{5}$

Jika dilihat dari pemuatan unsur-unsur (syarat-syarat) dipidananya percobaan kejahatan dalam Pasal 53 ayat (1) KUHP, maka dapat ditarik suatu kesimpulan bahwa:

1. Pada perbuatan percobaan kejahatan dapat dipidana, jika telah memenuhi unsurunsur yang terdapat dalam Pasal 53 ayat (1) KUHP dan secara a contrario (cara menafsirkan undang-undang yang didasarkan pada perlawanaan pengertian antara permasalahan yang dihadapi dan permasalahan yang diatur dalam undangundang), namun ada pula percobaaan kejahatan yang tidak dapat dipidana, jika salah satu unsur - unsur percobaan kejahatan tidak dapat terpenuhi;

2. Bahwa ada pula percobaan kejahatan yang secara tegas oleh UU dirumuskan percobaan yang tidak dapat dipidana, contoh pada percobaan penganiayaan biasa (Pasal 351 ayat (5) KUHP), percobaan penganiayaan hewan (Pasal 302 ayat (4) KUHP), percobaan perang tanding (Pasal 284 ayat (5) KUHP);

3. Percobaan melakukan pelanggaran juga tidak dapat dipidana (dipertegas dengan adanya Pasal 54 KUHP);

4. Percobaan kejahatan yang dapat dikenai sanksi pidana hanya diatur pada tindak pidana yang dilakukan dengan kesengajaan (dolus) dan tidak ada sanksi pidana dalam tindak pidana kealpaan (culpa). Bahwa istilah niat merupakan bagian kesengajaan, karena perbuatan tersebut merupakan tindak pidana yang disadari juga dikehendaki oleh pelaku. Sedangkan kealpaan adalah tindakan kecerobohan/ kurang berhati-hati dari pelaku yang berakibat tindak pidana culpa;

5. Percobaan tidak dapat terjadi pada tindak pidana pasif(delik ommisionis), sebab tindak pidana ommisionis pelanggaran terhadap instruksi/perintah yang dalam hal ini tidak melakukan yang diinstruksikan;

6. Terdapat beberapa perbuatan kejahatan yang sifat dari kejahatan tersebut telah dirumuskan tidak mungkin terjadi percobaannya, yaitu:

a. Bahwa dalam perbuatan percobaan dalam suatu perkara dimana telah timbul niat kemudian telah ada permulaan pelaksanaan sebagaimana dimaksud pasal 53 KUHP, dapat dirumuskan merupakan kejahatan selesai, seperti perbuatan makar yang diatur dalam Pasal 104 KUHP yang bermaksud membunuh, merampas kemerdekaan atau meniadakan kemampuan Presiden dan Wakilnya. Kemudian Pasal 106 KUHP dengan maksud agar seluruh atau sebagian wilayah Indonesia jatuh ketangan musuh atau memisahkan sebagian wilayah negara dan Pasal 107 KUHP yang bermaksud menggulingkan pemerintahan;

b. Bahwa unsur perbuatan yang dilarang dari kejahatan, misalnya Pasal 163 bis ayat (1) KUHP atau pasal 391 KUHP.

Disamping hal tersebut diatas, R. Soesilo mengatakan bahwa syarat- syarat yang harus dipenuhi agar suatu percobaan agar percobaan pada kejahatan dapat dihukum,

5 ibid.[185]. 
adalah sebagai berikut :

1. Niat untuk melakukan tindak pidana telah ada, artinya orang yang sudah mempunyai niat untuk melakukan tindak pidana yang meliputi sifat kesengajaan (dolus), oleh karena percobaan pada kejahatan bersifat kealpaan (culpa) tidak mungkin terjadi;

2. seseorang yang melakukan perbuatan melawan hukum tersebut, maksudnya orang tersebut bukan hanya memikirkan saja, tetapi sudah harus mulai ada tindakan awal/perbuatan persiapan;

3. Perbuatan pidana tersebut belum diselesaikan, namun terhalang oleh sebabsebab yang timbul pertengahan pelaksanaan tersebut. Belum terselesainya perbuatan pidana tersebut maksudnya adalah belum semua unsur-unsur dari kejahatan tersebut selesai, contohnya delik materiil, namun akibat dari delik tersebut belum terjadi;

4. Sebab-sebab itu tidak terletak dalam kemauan pembuat kejahatan itu sendiri, maksudnya tidak dari kemauan sendiri mundur dari mengerjakan kejahatan itu, sebab harus dari luar, misalnya dalam mencuri, karena kepergok / ketahuan orang. ${ }^{6}$

Batas antara perbuatan persiapan dan perbuatan pelaksanaan dari peristiwa pidana itu tidak mudah untuk dijelaskan. Pada umumnya perbuatan tersebut dapat diasumsikan sebagai perbuatan pelaksanaan, apabila orang telah melakukan suatu bagian dari suatu peristiwa pidana, jika seseorang belum memulai bagian dari suatu tindak pidana, maka perbuatannya itu haruslah dipandang sebagai perbuatan persiapan. ${ }^{7}$ UU KUHP juga mengatur tentang hukuman terhadap "perbuatan persiapan" maupun terhadap tindak pidana tertentu yang secara tegas dinyatakan dalam undang-undang. Dalam RUU KUHP, "perbuatan persiapan" dikualifikasi sebagai tindak pidana, apabila perbuatan tersebut berkaitan dengan tindak pidana terorisme.

RUU KUHP juga mengkategorikan pengertian tentang "permulaan pelaksanaan" yang merupakan salah satu syarat untuk mengkategorikan perbuatan sebagai suatu "percobaan tindak pidana". Perumusan definisi tersebut mempunyai pengaruh positif karena dapat memberikan kepastian hukum dalam menentukan suatu perbuatan yang dapat dikatakan sebagai "percobaan tindak pidana”. Secara tidak langsung, perumusan tersebut juga memudahkan untuk membedakan suatu perbuatan, apakah merupakan "percobaan tindak pidana"

${ }^{6}$ I Made Widnyana, 'Hukum Pidana II (FH Unud, Denpasar)' [1992] Yuridika.[11].

${ }^{7}$ R. Soesilo, Pokok-Pokok Hukum Pidana Peraturan Umum Dan Delik-Delik Khusus (1984).[69]. 
atau semata-mata sebagai suatu "persiapan tindak pidana". Terdapat perbaikan konsep sebagaimana diatur dalam Pasal 28 RUU terkait penangkapan terhadap "seseorang yang diduga melakukan tindak pidana terorisme harus didasarkan pada bukti permulaan yang cukup". Mengenai pengertian bukti permulaan yang cukup, pengertiannya hampir sejenis yang dirumuskan Pasal 183 KUHAP yakni sesuai dengan prinsip "batas minimal pembuktian" yang terdiri dari minimal dua alat bukti, bisa terdiri dari minimal dua orang saksi ditambah dengan alat bukti lain. Dengan aturan yang lebih ketat, dalam tahap penyidikan tidak dapat ceroboh untuk menangkap seseorang yang diduga melakukan tindak pidana, kemudian baru dicari untuk dibuktikan unsur pembuktiannya. Prosedur kerja dari para penyidik inilah yang harus dirubah, para penyidik harus melakukan penyidikan yang cermat dengan teknik dan taktis investigasi yang mampu mengumpulkan bukti sehingga didapat alat bukti yang cukup sebagai pembuktian kemudian barulah dilakukan pemeriksaan pada tingkat penyidikan kemudian dilakukan penangkapan dan berakhir di penahanan penahanan.

Bahwa dalam revisi UU Pemberantasan Tindak Pidana Terorisme ini terdapat beberapa penambahan substansi atau norma baru untuk menguatkan peraturan dalam UU sebelumnya. Setidaknya terdapat delapan poin penambahan substansi atau norma baru yaitu :

a. Kriminalisasi terhadap berbagai aturan baru tindak pidana terorisme seperti penjualan terhadap jenis bahan peledak maupun bahan dasar yang dijadikan bahan peledak, seseorang yang mengikuti pelatihan militer atau paramiliter atau latihan lain baik di dalam negeri maupun luar negeri dengan maksud mempersiapkan tindak pidana terorisme;

b. Penjatuhan sanksi pidana yang lebih berat terhadap pelaku tindak pidana terorisme baik permufakatan jahat, persiapan, percobaan dan pembantuan untuk melakukan tindak pidana terorisme;

c. Pemberatan sanksi pidana terhadap korporasi yang dikenakan kepada pendiri, pemimpin, pengurus, atau orang-orang yang mengarahkan kegiatan korporasi yang diduga sebagai organisasi terorisme;

d. Penjatuhan pidana tambahan berupa pencabutan hak untuk memiliki paspor dalam jangka waktu tertentu kepada seseorang yang terafiliasi dengan kelompok tindak pidana terorisme;

e. Revisi penambahan waktu penangkapan, penahanan dan perpanjangan penangkapan dan penahanan untuk kepentingan penyidik dan penuntut umum 
serta penelitian berkas perkara tindak pidana terorisme oleh penuntut umum dimana penambahan waktu ini menjamin bahwa penegak hukum tidak gegabah dalam menyimpulkan seseorang sebagai pelaku tindak pidana terorisme serta menjamin hak dari para pelaku terorisme;

f. Perlindungan korban tindak pidana terorisme sebagai bentuk tanggung jawab negara yang berupa bantuan medis, rehabilitasi psikologis, santunan terhadap korban dan biaya kompensasi;

g. Pencegahan tindak pidana terorisme dengan melakukan langkah antisipasi melalui kesiapsiagaan nasional, kontra radikalisasi dan deradikalisasi yang dilakukan oleh instansi yang terkait dengan pencegahan tindak pidana terorisme;

h. Kelembagaan BNPT dan pengawasannya serta peran TNI. ${ }^{8}$

Dengan demikian perbuatan yang terkena tindak pidana terorisme dalam undangundang baru antara lain :

1. Memperjualbelikan bahan dasar kimia sebagai bahan peledak, atau memperjualbelikan senjata kimia, senjata biologi, mikro organisme, nuklir dan bahan radio aktif dan komponennya (sesuai dengan Pasal 10A ayat (1));

2. Setiap orang yang melakukan tindak pidana terorisme di wilayah kesatuan Republik Indonesia, atau di negara lain, merencanakan, menggerakkan atau mengorganisasikan tindak pidana terorisme dengan orang yang berada di dalam negeri, dan atau di luar negeri, atau negara asing (sesuai dengan Pasal 12A ayat $(1))$

3. Setiap orang yang dengan sengaja menjadi anggota atau merekrut anggota, merekrut orang untuk menjadi anggota korporasi yang di tetapkan atau di putuskan pengadilan sebagai organisasi terorisme (sesuai dengan Pasal 12A ayat (2));

4. Pendiri, pemimpin pengurus atau orang yang mengendalikan kegiatan korporasi terorisme (sesuai dengan Pasal 12A ayat (3));

5. Orang yang dengan sengaja menyelenggarakan, memberikan atau mengikuti pelatihan militer, pelatihan para militer, atau pelatihan lain baik di dalam negeri maupun di luar negeri, dengan maksud merencanakan mempersiapkan atau mempersiapkan tindak pidana terorisme (sesuai dengan Pasal 12B ayat (1));

6. Setiap orang yang dengan sengaja merekrut, menampung atau mengirim orang untuk mengikuti pelatihan (sesuai dengan Pasal 12B ayat (2)). ${ }^{9}$

Penambahan di Pasal 12A dan 12B ini ditujukan untuk memuat perbuatan persiapan selain itu dapat menjangkau juga dalam bentuk perbuatan pendahuluan seperti rekrutmen anggota setelah itu dibentuk suatu organisasi terorisme dan

8 Bayu Septianto, 'Revisi UU Terorisme Disahkan DPR, Berikut Poin-Poin Perubahannya' (Okenews, 2018) <https://nasional.okezone.com/read/2018/05/25/337/1902632/revisi-uu-terorisme-disahkan-dpr-berikut-poin-poin-perubahannya> accessed 24 September 2019.

9 Yudho Winarto, 'Perbuatan Yang Terkena Tindak Pidana Terorisme' (Kontan.co.id, 2018) $<$ https://nasional.kontan.co.id/news/perbuatan-yangterkena-tindak-pidana-terorisme $>$ accessed 20 September 2019. 
setelah terbentuk kemudian dilakukan pembaiatan dan mulai dilakukan pelatihan sampai dengan berbagai kegiatan radikal yang terindikasi terhadap perbuatan persiapan. Bahwa dalam dua pasal tersebut juga terdapat aspek pencegahan yakni mengizinkan bagi aparat penegak hukum untuk menindak organisasi teroris kemudian dalam Undang-Undang PTPTerorisme ini juga menyusun ketentuan penetapan dalam keterlibatan organisasi terorisme tanpa melalui putusan pengadilan yang berkekuatan hukum tetap melainkan hanya melalui penetapan hakim yang kemudian dalam revisi pada Undang-Undang PTP Terorisme ini dapat menindak dan menjatuhi pidana dan pencabutan hak-hak tertentu bagi para pelaku berupa pencabutan hak untuk memiliki paspor dan pas lintas batas dalam jangka waktu paling lama 5 (lima) tahun sehingga aksi para teroris tersebut dapat ditindak sebelum aksi mereka dilakukan.

\section{Pertanggungjawaban Pidana Pelaku Perbuatan Persiapan dalam Tindak}

\section{Pidana Terorisme}

Paling awal yang menyatakan mengenai kondisi batin dari seseorang yang melakukan perbuatan tindak pidana, dalam ilmu hukum pidana disebut juga pertanggungjawaban hukum, kemudian perihal kedua yakni hubungan antara batin seseorang yang melakukan tindak pidana dengan perbuatan yang dilakukan dengan sifatnya kesengajaan maupun karena sifat kealpaan, sehingga seseorang mampu untuk mempertanggungjawabkan, mempunyai sifat kesengajaan ataupun kealpaan kemudian tidak adanya alasan pemaaf bagi seseorang yang melakukan tindak pidana merupakan unsur-unsur dari kesalahan. Bahwa perbuatan yang dilakukan yang bersifat kesengajaan maupun kealpaan apabila dilakukan oleh seseorang yang tidak mampu mempertanggungjawabkan perbuatannya, begitu juga dengan perbuatan yang tidak dapat dipikirkan mengenai unsur alasan pemaaf, apabila seseorang tidak mampu bertanggung jawab atas perbuatan yang dilakukan. Bahwa tidak dapat dipertanggungjawabkan perbuatan seseorang apabila perbuatan tersebut belum bersifat melawan hukum, maka perbuatan yang dapat dipertanggungjawabkan harus ada perbuatan pidana yang dilakukan oleh seseorang dan semua unsur tersebut 
harus dihubungkan pula dengan perbuatan pidana yang dilakukan. ${ }^{10}$ Untuk adanya kesalahan seseorang harus :

1. Seseorang yang melakukan perbuatan pidana (bersifat melawan hukum);

2. Batas usia dewasa seseorang yang mampu bertanggungjawab;

3. Adanya kesalahan yang berupa kesengajaan dan kealpaan;

4. Tidak adanya alasan pemaaf. ${ }^{11}$

Bahwa yang dimaksud dengan pelaku tindak pidana adalah:

\section{a. Orang yang melakukan (Pleger)}

Orang yang melakukan (pleger) adalah seseorang yang melakukan suatu tindak pidana yang dilakukan hanya seorang diri. Mereka yang terlibat melakukan tindak pidana (plegen) jika mengarah kepada orang yang melakukan tindak pidana disebut dengan pembuat pelaksana (pleger), bahwa orang yang melakukan perbuatan kemudian perbuatan tersebut menimbulkan suatu tindak pidana karena tanpa adanya perbuatan dari pelaku tindak pidana ini, maka tindak pidana tersebut tidak akan dapat terlaksana, oleh karena itu dapat disimpulkan bahwa syarat seorang pleger adalah sama dengan syarat seorang dader, namun ada perbedaan pleger dengan dader yakni terhadap pleger masih dibutuhkan keterlibatan orang lain baik secara fisik maupun psikis, hanya saja keterlibatan orang lain tersebut harus dengan perbuatan yang serupa sehingga perbuatan tersebut tidak sebagai penentu dalam mewujudkan tindak pidana yang akan dilakukan. ${ }^{12}$

Umumnya "pelaku" dapat diketahui yaitu:

1. Delik formil, pelakunya melakukan perbuatan pidana yang telah selesai dilakukan dan memenuhi perumusan pasal dalam undang-undang.

2. Delik materil, pelakunya melakukan perbuatan pidana yang telah selesai dilakukan dan timbulnya akibat dari perbuatan tersebut yang diancam dengan hukuman oleh undang-undang.

3. Delik yang memuat unsur kualitas atau kedudukan, pelakunya yang memiliki unsur, kedudukan atau kualitas sebagai yang dirumuskan dalam undang-undang.

\footnotetext{
${ }^{10}$ Saifullah, Buku Ajar Konsep Hukum Pidana (2004).[27-28].

${ }^{11}$ Moeljatno, Asas-Asas Hukum Pidana (Rieneka Cipta 2010).[164].

12 Mohammad Ekaputra dan Abdul Khair, Percobaan Dan Penyertaan (USU Press 2009). [44].
} 
Misalnya, kejahatan jabatan adalah pejabat pegawai negeri. ${ }^{13}$

\section{b. Yang menyuruh melakukan/memberi perintah (doen pleger)}

Dalam hal ini sedikitnya ada dua orang yang menyuruh (doen pleger) dan yang disuruh (plegen). Bahwa kesimpulannya bukan hanya seseorang tersebut yang melakukan peristiwa pidana, akan tetapi juga memerintahkan orang lain. Bahwa syarat yang utama dalam bentuk menyuruh melakukan adalah seseorang yang diperintahkan untuk melakukan sesuatu namun tidak dapat dipertanggungjawabkan secara pidana. Jika dijabarkan syarat-syarat bentuk penyertaan dalam menyuruh melakukan adalah sebagai berikut:

- Ada orang yang dengan maksud melakukan tindak pidana;

- Orang tersebut tidak melakukan perbuatan secara sendiri;

- Menyuruh orang lain untuk melakukan perbuatan tindak pidana;

- Orang yang disuruh melakukan perbuatan pidana adalah orang yang tidak dapat dipertanggungjawabkan secara hukum. ${ }^{14}$

\section{c. Orang yang turut serta melakukan (dader)}

Bahwa dalam hal turut serta melakukan ini para pelaku harus berjumlah dua orang yang secara bersama-sama melakukan suatu tindak pidana, mereka ini secara sadar dan mengerti kemudian bersama-sama melakukan tindak pidana tertentu, oleh karena itu mereka juga secara bersama-sama dapat pula dipertanggungjawabkan atas tindak pidana yang mereka lakukan. ${ }^{15}$ Prof. Satochid Kartanegara berpendapat orang yang memiliki keterlibatan langsung dalam tindak pidana maupun memberikan bantuan dalam tindak pidana (mededader) harus memenuhi 2 (dua) syarat, yaitu:

1. Harus ada kerja sama secara fisik;

2. Harus ada kesadaran untuk bekerjasama.

Selanjutnya Prof. Satochid Kartanegara mengutarakan :

"Mengenai syarat kesadaran kerjasama itu dapat diterangkan bahwa kesadaran itu perlu timbul sebagai akibat pemufakatan yang diadakan oleh para peserta. Akan tetapi, sudah cukup dan terdapat kesadaran kerja sama

13 Laden Marpaung, Unsur-Unsur Perbuatan Yang Dapat Dihukum (Delik) (Sinar Grafika 1991).[95].

${ }^{14}$ Mohammad Ekaputra dan Abdul Khair (n 12).Op.Cit.[50].

${ }^{15}$ Abdul Wahid, Kejahatan Terorisme, Perspektif Agama, HAM, Dan Hukum (Refika Aditama 2004).[72]. 
apabila para peserta pada saat mereka melakukan kejahatan itu sadar bahwa mereka bekerja sama". ${ }^{16}$

\section{d. Orang yang membujuk melakukan (uitlokker)}

Pada perbuatan pidana membujuk melakukan ini pelakunya minimal dua orang, yakni seorang pelaku bertugas untuk membujuk, kemudian pelaku yang lain menggerakkan orang untuk melakukan perbuatan pidana dan orang yang dibujuk tersebut dengan kesadaran melakukan tindak pidana sesuai dengan perintah dan kesemua pelaku tersebut dapat dimintai pertanggungjawaban.

Orang yang membujuk melakukan (uitlokker) adalah setiap perbuatan yang memerintahkan orang lain untuk melakukan suatu perbuatan pidana dengan cara dan upaya yang telah dirumuskan dalam pasal 55 ayat (1) ke- 2 KUHP. Menurut ajaran yang terdapat dalam KUHP, orang yang memerintahkan/membujuk orang lain untuk melakukan tindak pidana disebut actor intelectualis atau intelectueel dader atau provocateur atau uitlokker. Orang yang sengaja membujuk (uitlokker) dengan orang yang menyuruh (doenpleger) memiliki persamaan, yaitu sama-sama menggerakkan orang lain.

Adapun perbedaannya adalah:

1. Pada pertanggungjawaban pidana, yaitu pada pelaku doenpleger tidak dapat dipertanggungjawabkan perbuatannya, sedangkan pada pelaku uitlokker dapat dipertanggungjawabkan perbuatannya;

2. Cara-cara menggerakkan orang lain (pelaku) tersebut, pada uitlokker ditentukan dalam pasal 55 ayat (1) ke-2 KUHP, sedang pada doenpleger tidak ditentukan. Berdasarkan rumusan pasal 55 ayat (1) ke-2 KUHP, dapat diketahui unsur-unsur uitlokker (membujuk) sebagai berikut:

1. Kesengajaan pelaku yang dalam hal ini adalah pembujuk yang ditujukan kepada perbuatannya sesuai delik tertentu oleh yang dibujuk;

2. Membujuk orang lain sesuai dengan unsur dalam pasal 55 ayat (1) ke-2 KUHP;

3. Orang yang dibujuk tersebut melakukan perbuatan yang telah diatur dalam delik

${ }^{16}$ Marpaung (n 13)., Loc. Cit.[48]. 
tertentu setidaknya dalam melakukan percobaan; ${ }^{17}$

Pertanggungjawaban pidana tersebut harus memuat asas tiada hukuman tanpa kesalahan (asas culpabilitas), yang didasarkan pada keseimbangan monodualistik bahwa asas kesalahan yang didasarkan pada nilai keadilan harus disejajarkan berpasangan dengan asas legalitas yang mengandung makna bahwa setiap perbuatan harus didasari kepada peraturan perundang-undangan yang berlaku, walaupun pertanggungjawaban pidana berdasarkan kesalahan, namun dalam beberapa hal tidak menutup kemungkinan adanya pertanggungjawaban pidana yang dibebankan kepada seseorang atas perbuatan orang lain (vicarious liability) dan pertanggungjawaban yang ketat (strict liability) yang dapat diartikan seseorang dapat dipertanggungjawabkan untuk tindak pidana yang dilakukannya meskipun orang tersebut tidak mempunyai kesalahan namun perilaku orang tersebut secara nyata telah melanggar ketentuan pidana. Masalah kesesatan (error) yang berupa kesesatan tentang keadaannya (error facti) maupun kesesatan tentang ajaran hukum yang sesuai dengan konsep merupakan salah satu unsur alasan pemaaf sehingga pelaku tidak dijatuhi hukuman kecuali kesesatan tersebut layak dipersalahkan kepadanya. ${ }^{18}$

Seseorang dapat dipertanggungjawabkan atas tindakannya apabila tindakan tersebut bersifat melawan hukum kemudian tidak ada alasan pembenar atau peniadaan sifat melawan hukum untuk pidana yang telah dilakukannya. Bahwa seseorang dapat dikatakan mampu bertanggung jawab atas tindakan yang telah diperbuat, maka tindakan tersebut yang dapat dipertanggungjawabkan atas perbuatannya. Tindak pidana jika tiada hukuman tanpa kesalahan yang merupakan maksud dari asas culpabilitas, oleh karena itu ancaman hukuman bagi seseorang yang melakukan tindak pidana bergantung dari tingkat kesalahan yang dilakukan oleh orang tersebut. Kesalahan tersebut yang harus dapat dipertanggungjawabkan oleh seseorang dalam melakukan kesalahan dan untuk membuktikan adanya

\footnotetext{
${ }^{17}$ ibid. [85].

${ }^{18}$ Barda Nawawi Arief, Masalah Penegakan Hukum Dan Kebijakan Penanggulangan Kejahatan (PT Citra Aditya Bakti 2001).[23].
} 
unsur kesalahan tersebut, maka juga harus dibuktikan kembali. Bahwa untuk membuktikan unsur kesalahan tersebut juga tidaklah mudah dan membutuhkan waktu, maka unsur bertanggung jawab harus selalu ada karena setiap orang yang sehat secara jasmani maupun rohani memiliki kemampuan untuk bertanggung jawab, namun dapat dikecualikan bahwa seseorang yang melakukan tindak pidana memiliki gangguan kejiwaan. Pengecualian tersebut Jaksa maupun Hakim dapat memerintahkan kepada penyidik untuk dilakukan pemeriksaan gangguan kejiwaan lebih lanjut di rumah sakit jiwa untuk dilakukan observasi, dan jika hasil observasi tersebut menyatakan bahwa seseorang tersebut memiliki gangguan kejiwaan maka kemampuan untuk mempertanggungjawabkan akan berhenti, sehingga kesalahan tidak ada dan pidana tidak dapat dijatuhkan berdasarkan asas tidak dipidana jika tidak ada kesalahan. ${ }^{19}$ Bahwa unsur pertanggung jawaban pidana adalah:

1. Adanya suatu tindakan pidana;

2. Dilakukan atas dasar kehendak sendiri;

3. Pelaku menyadari atas perbuatan yang dilakukan maupun akibat yang ditimbulkan dari perbuatan tersebut. ${ }^{20}$

Pengklasifikasian Pasal 25 Undang-Undang RI Nomor 15 Tahun 2003 tentang Pemberantasan Tindak Pidana Terorisme, dalam memecahkan kasus-kasus tindak pidana terorisme, maka hukum acara yang berlaku di Indonesia sampai dengan sekarang ini adalah Undang- Undang Nomor 8 Tahun 1981 tentang Hukum Acara Pidana (Kitab Undang- Undang Hukum Acara Pidana/KUHAP). Bahwa dalam implementasi Undang-Undang khusus ini tidak boleh berlawanan dengan asas umum hukum pidana dan hukum acara pidana yang telah ada, namun pada realitanya terdapat ketentuan dalam beberapa pasal di Undang-Undang tersebut yang menyimpangi asas umum hukum pidana dan hukum acara pidana. Penyimpangan tersebut pada dasarnya memangkas hak seseorang yang melakukan tindak pidana terorisme untuk mendapatkan Hak Asasi Manusia, jika dibandingkan dengan asas-asas yang terdapat dalam Kitab Undang-Undang Hukum Pidana (KUHP).

\footnotetext{
${ }_{19}$ Marpaung (n 13)., Loc. Cit. [49].

${ }^{20}$ Andi Hamzah, Asas-Asas Hukum Pidana (Rineka Cipta 2008).[72].
} 
Apabila memang diperlukan suatu penyimpangan tersebut, maka harus dicari yang mendasari penyimpangan tersebut, karena setiap perubahan tersebut akan selalu berkaitan erat dengan Hak Asasi Manusia. ${ }^{21}$ bahwa Undang-Undang Pemberantasan Tindak Pidana Terorisme mempunyai sifat sebagai Undang- Undang yang khusus, maka dalam hal ini tidak terjadi penyimpangan asas, tetapi lebih mengarah kepada pengkhususan asas yang memakai dasar asas umum, namun dibuat khusus sesuai dengan ketentuan-ketentuan yang bersifat khusus yang diatur oleh Undang-Undang khusus tersebut.

Di dalam Pasal 6 UU No. 15 Tahun 2003 dinyatakan bahwa pengertian tindak pidana terorisme yaitu:

"Setiap orang yang dengan sengaja menggunakan kekerasan atau ancaman kekerasan menimbulkan suasana teror atau rasa takut terhadap orang secara meluas atau menimbulkan korban yang bersifat massal, dengan cara merampas kemerdekaan atau hilangnya nyawa dan harta benda orang lain, atau mengakibatkan kerusakan atau kehancuran terhadap obyek-obyek vital yang strategis atau lingkungan hidup atau fasilitas publik atau fasilitas internasional, dipidana dengan pidana mati atau penjara seumur hidup atau pidana penjara paling singkat 4 (empat) tahun dan paling lama 20 (dua puluh) tahun".

Kemudian dirubah ancaman pidananya di undang-undang baru Pasal 6 yakni pidana paling singkat selama 5 (lima) tahun penjara. Bahwa sanksi hukuman untuk pelaku tindak pidana terorisme diatur secara tersendiri, karena perbuatan terorisme memiliki pengertian yang cukup luas termasuk perusakan lingkungan hidup yakni didalam Pasal 7 UU No. 15 Tahun 2003 menyatakan bahwa:

"Setiap orang yang dengan sengaja menggunakan kekerasan atau ancaman kekerasan bermaksud untuk menimbulkan suasana teror atau rasa takut terhadap orang secara meluas atau menimbulkan korban yang bersifat massal dengan cara merampas kemerdekaan atau hilangnya nyawa atau harta benda orang lain, atau untuk menimbulkan kerusakan atau kehancuran terhadap obyek-obyek vital yang strategis, atau lingkungan hidup, atau fasilitas publik, atau fasilitas internasional, dipidana dengan pidana penjara paling lama seumur hidup". ${ }^{22}$

${ }^{21}$ Loeby Loqman, Percobaan,Penyertaan Dan Gabungan Tindak Pidana (Universitas Tarumanegara 1996).[13].

22 ibid.[13]. 
Bagi seseorang yang memasukkan atau menguasai ke Indonesia secara illegal berupa bahan peledak maupun senjata api yang tidak memiliki ijin dengan pihak yang terkait yang ditujukan untuk kepentingan tindak pidana terorisme diancam pidana dengan pidana mati atau penjara seumur hidup atau pidana penjara paling singkat 3 (tiga) tahun dan paling lama 20 (dua puluh) tahun seuai dengan Pasal 9 UU No. 15 Tahun 2003.

Bagi mereka/orang yang dengan sengaja dan melawan hukum memperdagangkan bahan-bahan utama yang potensial untuk digunakan sebagai bahan peledak kemudian digunakan dalam tindak pidana terorisme, maka ancaman hukuman bagi pelaku yakni penjara paling singkat 2 (dua) tahun dan paling lama 7 (tujuh) tahun sesuai Pasal 10A ayat (2) dan diayat (3) dijelaskan jika telah terbukti penjualan dalam hal bahan potensial atau komponen sebagaimana dimaksud pada ayat (2) terbukti digunakan dalam tindak pidana terorisme dipidana paling singkat 4 (empat) tahun dan paling lama 15 (lima belas) tahun sesuai UU Pemberantasan Tindak Pidana Terorisme yang baru.

Bagi orang yang dengan sengaja memberikan bantuan atau kemudahan terhadap pelaku tindak pidana terorisme, dengan:

a. memberikan atau meminjam uang atau barang atau harta kekayaan kepada pelaku tindak pidana terorisme;

b. menyembunyikan pelaku tindak pidana terorisme;

c. menyembunyikan informasi termasuk tindak pidana terorisme dipidana dengan pidana penjara paling singkat 3 (tiga ) tahun dan paling lama 15 (lima belas) tahun.

Bahwa memberikan bantuan adalah usaha menyerahkan pertolongan baik sebelum maupun pada saat terjadi tindak pidana terorisme. Sedangkan kemudahan adalah perbuatan memberikan bantuan setelah tindak pidana dilakukan. ${ }^{23}$

\section{Kesimpulan}

UU terorisme terdahulu dinilai kurang mengakomodir perbuatan pelaku dalam melakukan tindak pidana terorisme. Bahkan UU yang lama membuat negara

${ }^{23}$ Moch. Faisal Salam, Motivasi Tindakan Terorisme (Mandar Maju 2005).[219]. 
cenderung bersikap kurang responsif dalam menangani kasus terorisme. Bahwa aparat penegak hukum dan keamanan hanya bisa bertindak ketika terjadi kejadian/ peristiwa sehingga negara sangat kesulitan mencegah aksi terorisme di Indonesia. UU Pemberantasan Tindak Pidana Terorisme yang baru tersebut menekankan langkahlangkah pencegahan karena jika telah ada perbuatan persiapan yang dilakukan oleh para pelaku teror tersebut, maka aparat penegak hukum dapat melakukan upaya pencegahan dan melakukan penangkapan kepada pihak-pihak yang terkait.

Pelaku yang sudah merencanakan maupun sudah ada perbuatan persiapan dibandingkan dengan pelaku yang telah selesai melakukan perbuatannya ini jika dilihat dari ancaman hukumannya, yakni sama beratnya namun dalam pembuktian ini harus disertai dengan bukti-bukti yang ada dan valid jika pelaku sudah merencanakan maupun yang telah melakukan perbuatan teror.

Revisi Undang-Undang Pemberantasan Tindak Pidana Terorisme ini merupakan upaya pemerintah dalam melakukan tindakan preventif untuk melakukan pencegahan dan mendeteksi secara dini terhadap terduga teroris serta upaya untuk penambahan kewenangan dari aparat penegak hukum atau dengan kata lain pemerintah harus tanggap dengan keberadaan terduga terorisme mulai dari tahapan menyusun konsep tindak pidana terorisme, tahap pelaksanaan dan tahap penyelesaian yang merupakan dasar politik hukum pidana untuk melahirkan peraturan yang tanggap dan cepat dalam menyelesaikan kasus terorisme sehingga radikalisme dapat dicegah.

Dalam melaksanakan pemberantasan terorisme terutama terhadap kelompok teror yang mulai berkembang di Indonesia, perlu adanya pengaturan keamanan nasional terhadap perlindungan dari ancaman terorisme. Saat ini Indonesia telah memiliki draft RUU Keamanan Nasional yang diinginkan pada masa yang akan datang karena RUU tersebut dapat menjadi wadah hukum yang cocok untuk menjadikan kondisi keamanan nasional yang mendukung sehingga mampu mencegah terjadinya aksi teror di Indonesia. ${ }^{24}$

${ }^{24}$ Debora Sanur L, 'Upaya Penanggulangan Terorisme Isis Di Indonesia Dalam Melindngi Keamanan Nasional’ (2016) 7 Politica.[44]. 
Proses deradikalisasi merupakan penyeimbang dari pendekatan penegakan hukum (law enforcement) dengan memakai sarana hukum pidana. Melalui Pendekatan non penal maka tindakan represif terhadap radikalisme dan berbagai bentuk terorisme dilakukan dari penyebab terjadinya berbagai pikiran radikalisme dan usaha untuk mengatasi tanpa menggunakan hukum pidana.

Deradikalisasi juga dapat dimaksudkan mengantisipasi sebelum radikalisme terbentuk. Deradikalisasi adalah suatu upaya mengurangi kegiatan-kegiatan radikal dan menghilangkan paham radikal bagi mereka yang terlibat teroris dan para pengikut serta anggota masyarakat yang telah memiliki paham-paham radikal tertentu. Tujuan umum deradikalisasi adalah untuk membuat para teroris atau kelompok yang melakukan kekerasan bersedia melepaskan diri mereka dari aksi dan kegiatan teroris. Secara khusus tujuan deradikalisasi adalah pertama, membuat para teroris mau menghindarkan diri dari aksi terorisme dan kekerasan. Kedua kelompok radikal mendukung pemikiran yang saling bertoleransi antar umat manusia . Ketiga, para teroris yang mau berubah dapat mendukung program-program nasional dalam membangun kehidupan berbangsa dam bernegara dalam bingkai Negara Kesatuan Republik Indonesia. $^{25}$

\section{Daftar Bacaan}

\section{Buku}

Barda Nawawi Arief, Masalah Penegakan Hukum Dan Kebijakan Penanggulangan Kejahatan (PT Citra Aditya Bakti 2001).

Hamzah A, Asas-Asas Hukum Pidana (Rineka Cipta 2008).

Loeby Loqman, Percobaan,Penyertaan Dan Gabungan Tindak Pidana (Universitas Tarumanegara 1996).

Marpaung L, Unsur-Unsur Perbuatan Yang Dapat Dihukum (Delik) (Sinar Grafika 1991).

\footnotetext{
${ }^{25}$ Muhammad Ali Zaidan, 'Pemberantasan Tindak Pidana Terorisme (Pendekatan Kebijakan Kriminal)’ (2017) 3 Jurnal Universitas Negeri Semarang.[162].
} 
Moch. Faisal Salam, Motivasi Tindakan Terorisme (Mandar Maju 2005).

Moeljatno, Asas-Asas Hukum Pidana (Rieneka Cipta 2010).

Mohammad Ekaputra dan Abdul Khair, Percobaan Dan Penyertaan (USU Press 2009).

P.A.F Lamintang, Dasar-Dasar Hukum Pidana Indonesia (Sinar Baru 1990).

R. Soesilo, Pokok-Pokok Hukum Pidana Peraturan Umum Dan Delik-Delik Khusus (1984).

Saifullah, Buku Ajar Konsep Hukum Pidana (2004).

Wahid A, Kejahatan Terorisme, Perspektif Agama, HAM, Dan Hukum, (Refika Aditama 2004).

\section{Jurnal}

Debora Sanur L, 'Upaya Penanggulangan Terorisme Isis Di Indonesia Dalam Melindngi Keamanan Nasional' (2016) 7 Politica.

Muhammad Ali Zaidan, 'Pemberantasan Tindak Pidana Terorisme (Pendekatan Kebijakan Kriminal)’ (2017) 3 Jurnal Universitas Negeri Semarang.

Widnyana IM, 'Hukum Pidana II (FH Unud, Denpasar)' [1992] Yuridika.

\section{Artikel}

Bayu Septianto, 'Revisi UU Terorisme Disahkan DPR, Berikut Poin-Poin Perubahannya' (Okenews, 2018) <https://nasional.okezone.com/ $\mathrm{read} / 2018 / 05 / 25 / 337 / 1902632 /$ revisi-uu-terorisme-disahkan-dpr-berikutpoin-poin-perubahannya $>$ accessed 24 September 2019.

Indriyanto Seno Adji, 'Revisi UU Terorisme, Penegakan Hukum, Dan Perlindungan HAM' (Kompas, 2016) <https://nasional.kompas.com/ $\mathrm{read} / 2016 / 07 / 17 / 06414571 /$ revisi.uu.terorisme.penegakan.hukum.dan. perlindungan.ham?page $=$ all $>$.

Kawilarang RR., 'Mengenang Tragedi Bom Bali 2002' (2008) <https://www.viva.co.id/ arsip/2291-mengenang-tragedi-bom-bali-2002> accessed 20 September 2018.

Yudho Winarto, 'Perbuatan Yang Terkena Tindak Pidana Terorisme' (Kontan.co.id, 2018) <https://nasional.kontan.co.id/news/perbuatan-yangterkena-tindakpidana-terorisme $>$ accessed 20 September 2019. 


\section{Perundang-undangan}

Undang-Undang Republik Indonesia Nomor 8 Tahun 1981 tentang Hukum Acara Pidana.

Kitab Undang-Undang Hukum Pidana.

Peraturan Pemerintah Pengganti Undang-Undang (Perppu) Nomor 1 tahun 2002 tentang Pemberantasan Tindak Pidana Terorisme.

Peraturan Pemerintah Pengganti Undang-Undang Nomor 2 tahun 2002 tentang Pemberlakuan Peraturan Pemerintah Pengganti Undang-Undang Nomor 1 tahun 2002 tentang Pemberantasan Tindak Pidana Terorisme.

Undang-Undang Republik Indonesia Nomor15 Tahun 2003 tentang Penetapan Peraturan Pemerintah Pengganti Undang-Undang Nomor 1 tahun 2002 tentang Pemberantasan Tindak Pidana Terorisme menjadi Undang-Undang.

Undang-Undang Republik Indonesia Nomor 5 Tahun 2018 tentang Perubahan atas Undang-Undang Republik Indonesia Nomor 15 Tahun 2003 tentang Penetapan Peraturan Pemerintah Pengganti Undang-Undang Nomor 1 tahun 2002 tentang Pemberantasan Tindak Pidana Terorisme menjadi UndangUndang.

HOW TO CITE: Fandy Ardiansyah Catur Santosa, 'Pertanggungjawaban Pidana Pelaku Perbuatan Persiapan dalam Tindak Pidana Terorisme' (2019) Vol. 2 No. 3 Media Iuris. 
--Halaman ini sengaja dikosongkan-- 